\title{
Chronic intestinal pseudo-obstruction: Report of two cases
}

\author{
İki olgu nedeni ile kronik intestinal psödoobstruksiyon
}

Sabiye Akbulut*, Firdevs Topal, Nurten Savaş, Ahmet Erten, Emin Altıparmak

Department of Gastroenterology (S. Akbulut, MD), Kartal Koşuyolu High Specialty Education and Research Hospital, TR-34846 Istanbul, Department of Gastroenterology (F. Topal, MD), Çankırı State Hospital, TR-18100 Çankırı, Department of Gastroenterology (N. Savaş, MD), Department of Gastroenterology (E. Altıparmak, MD, A. Erten, MD), Ankara Numune Education and Research Hospital, TR-06100 Ankara

\begin{abstract}
Chronic intestinal pseudo-obstruction is a rare intestinal motility disorder. It is characterized by recurrent or persistent findings of intestinal obstruction in the absence of any mechanical obstruction. Various systemic or congenital diseases are held responsible in the etiology; moreover, it is accepted as idiopathic upon failure of detection of a true reason. We present hereby two rare cases who had been admitted with the symptoms of nausea, vomiting, constipation and tetany, and were diagnosed as chronic intestinal pseudo-obstruction.
\end{abstract}

Keywords: Chronic intestinal pseudo-obstruction, tetany, laparotomy

\section{Özet}

Kronik intestinal psödoobstrüksiyon nadir görülen bir intestinal motilite bozukluğudur. Herhangi bir mekanik obstrüksiyon olmaksızın intestinal obstrüksiyonun tekrarlayan veya devamlı bulguları ile karakterizedir. Etyolojide çeşitli sistemik veya konjenital hastalıklar yer alır, neden tesbit edilmediğinde idiopatik olarak kabul edilir. Biz burada bulantı, kusma, kabızlık ve tetani semptomları ile gelen, kronik intestinal psödoobstrüksiyon tanısı alan iki olguyu nadir görülmesi nedeniyle sunmaktayiz.

Anahtar sözcükler: Kronik intestinal psödoobstruksiyon, tetani, laparotomi

Geliş tarihi/Received: November 11, 2012; Kabul tarihi/Accepted: February 07, 2013

\section{*Corresponding author:}

Dr. Sabiye Akbulut, Gastroenteroloji Anabilim Dalı, Kartal Koşuyolu Yüksek İhtisas Eğitim ve Araştırma Hastanesi, TR-34846 Istanbul. E-mail: sabiye4@ hotmail.com

\section{Introduction}

Chronic intestinal pseudo-obstruction (CIPO) is a rare clinical syndrome of insufficient intestinal propulsion, which is characterized by symptoms and signs of bowel obstruction in the absence of any mechanical obstruction [1]. Although first defined by Dudley in [2, 3] 1958, the term chronic intestinal pseudo-obstruction (CIPO) found a place in the literature in 1970. The basic underlying pathology is the inability of the intestines to propel their contents forward due to motility impairment. As a result of neuromuscular changes which practically can involve any part of the digestive system [4].

CIPO is such a disease state that may be subjected to challenging and delayed diagnosis. The diagnosis is primarily based on case history, physical examination, laboratory and radiological examinations [1]. Herein, we present 2 cases of chronic intestinal pseudoobstruction who had been admitted with tetany as well as the symptoms and signs indicating intestinal obstruction in the absence of any mechanical obstruction. 


\section{Case report}

\section{Case report 1}

A 25 year-old female patient suffering from abdominal pain, nausea, vomiting, tetanic hand contractions resembling Trousseau sign and poor general condition was hospitalized in our clinic in an attempt to be investigated on. It was revealed from the patient's history that the abdominal pain, which could last around 1-2 hours or sometimes 2-3 days, had continued since her 14 years of age, was generally triggered by meals and in turn spreading throughout the abdominal region. She described a defecation-period history of every 3-5 days, followed by a moderate amelioration of the abdominal pain. She reported frequent admissions to emergency clinics due to abdominal pain and hand constructions in last one month. She was hospitalized in our clinic because of deterioration of her complaints, permanency of the vomiting and contractions in the hands.

Upon advancing into her past medical history, we revealed an appendectomy operation at 10 years of age and an explorative laparotomy performed to elucidate the mechanism involved in ileus at 21 years of age that actually yielded no clear reason. Her family history was unremarkable. In the physical examination, her general status was moderate with a relatively weak and dehydrated appearance. Trousseau sign was positive in both hands. She was conscious and able to cooperate; however, was unable to take food by mouth, with continuous vomiting upon oral feeding. He had blood pressure of 90/60 $\mathrm{mmHg}$, pulse rate of $88 / \mathrm{min}$ which was rhythmic, body mass index of $13.88 \mathrm{~kg} / \mathrm{m}^{2}$ (body wight: $30 \mathrm{~kg}$, height: $1.47 \mathrm{~m}$ ). Abdominal examination revealed bulging in the upper quadrants, distension in all abdomen and a scar tissue from a previous surgical operation. The bowel sounds was found to be diminished.

Results of the laboratory evaluation were as follows: Hemoglobin $10.30 \mathrm{~g} / \mathrm{dL}$ (12.3-15.3), white blood cell count 9.770/uL (4.4-11.3), and platelet count 362/uL (150-450), MCV $104 \mathrm{fL}$ (80-97), serum potassium $2.5 \mathrm{mmol} / \mathrm{L}$ (3.3-5.5), calcium $6.4 \mathrm{mg} / \mathrm{dL}$ (8.4-10.6), ionized calcium $3.9 \mathrm{mg} / \mathrm{dL}$ (4.2-5.2), albumin $48 \mathrm{~g} / \mathrm{L}$ (35-54), TSH $0.91 \mathrm{mU} / \mathrm{mL}(0.30-$ 4.00). Fasting blood glucose level, AST, ALT, ALP, GGT, total bilirubin, urea and creatinine levels were all within normal range. Blood plasma was negative for $\mathrm{HBsAg}$, antiHCV, antiHIV, ANA, antids-DNA, sc170, SLA, LKM, AMA, antigliadin antibody (AGA), anti-endomysium antibody (EMA) and tissue transglutaminase antibody. Standing plain abdominal x-ray depicted dilated bowel loops and air-fluid levels. Moreover, markedly dilated bowel loops and scattered air-fluid levels were also evident in abdominal computed tomography (Figure 1).

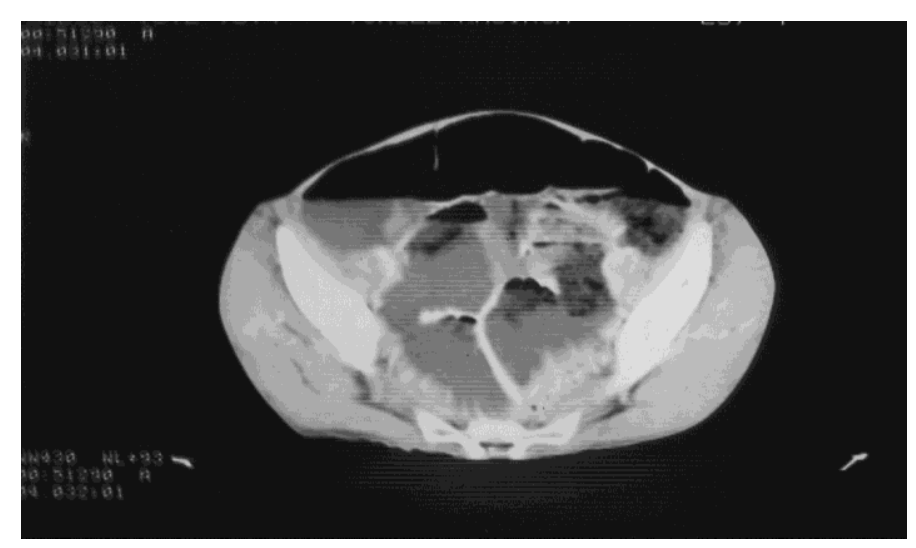

Figure 1. Case 1; abdominal tomographic image indicating markedly dilated intestinal loops and scattered air-fluid levels. 
Both colonoscopic and gastroscopic evaluations were normal; duodenal biopsy was unremarkable. Small bowel passage radiography reported dilated segments especially in the jejunum and a delayed passage. No passage into the colon was observed within 6.5 hours. The contrast agent was reported to pass into the colon only at the 24th hour of ingestion. The patient was diagnosed as chronic intestinal pseudo-obstruction. She had long-standing and sometimes exacerbating complaints in whom no mechanical obstruction could be detected in the gastrointestinal system on the basis of dilated jejunal segments displayed in the small bowel passage radiography and of passage into the colon at the 24th hour.

Bone mineral densitometry and hormonal measurements were implemented in the patient due to presence of growth retardation, low plasma calcium level and secondary amenorrhea. Results from bone mineral densitometry indicated osteoporosis (Respective T scores were -3.59 and -3.39 for L1-4 spine and femoral neck). Parathormon level was measured to be $98 \mathrm{pg} / \mathrm{mL}$ (N: 10-65). Serum 25-hyroxy vitamin D level declined to 15.6 $\mathrm{ng} / \mathrm{mL}(\mathrm{N}: 23-113)$, which was interpreted as secondary osteoporosis in response to osteomalasia. Fluid intake and output was carefully monitored, thereby performing necessary fluid, potassium and calcium replacements.

Following replacement, serum potassium and calcium levels increased to the respective normal values of $4.1 \mathrm{mg} / \mathrm{dL}$ and $5.5 \mathrm{mg} / \mathrm{dL}$; the nausea and vomiting complaints showed regression. Once oral calcium and vitamin D supplementation was initiated, Trousseau sign did not recur. Consequently, the patient was discharged from the hospital, being advised to take foods poor in fat, fiber and lactose, but rich in polypeptides and fluid content. The patient's diet was arranged into 6 or 8 meals, each being restricted to 200$300 \mathrm{kcal}$. Calcium and vitamin D preparation was prescribed to improve vitamin deficits. The patient came to her control visit 2 months after her discharge, with good general condition and complaining of no more tetany and vomiting.

\section{Case report 2}

A 24 year-old female patient was hospitalized for the complaints of constipation, bloating, nausea, vomiting and contractions in the hands. She reported that her complaints dated back to 14 years of age and were deteriorating especially following meals. She was commenced on treatment for the diagnosis of growth retardation, bradycardia, complete A-V block and hypogonadism at 12 years of age and in turn underwent a permanent pacemaker implantation. She reported to pass stool every 5 to 10 days, with incomplete bowel evacuation. The physical examination revealed an abdomen tender to palpation, diminished bowel sounds and Trousseau sign evident in both hands. Standing plain abdominal x-ray depicted a pacemaker shadow and air-fluid levels (Figure 2). 


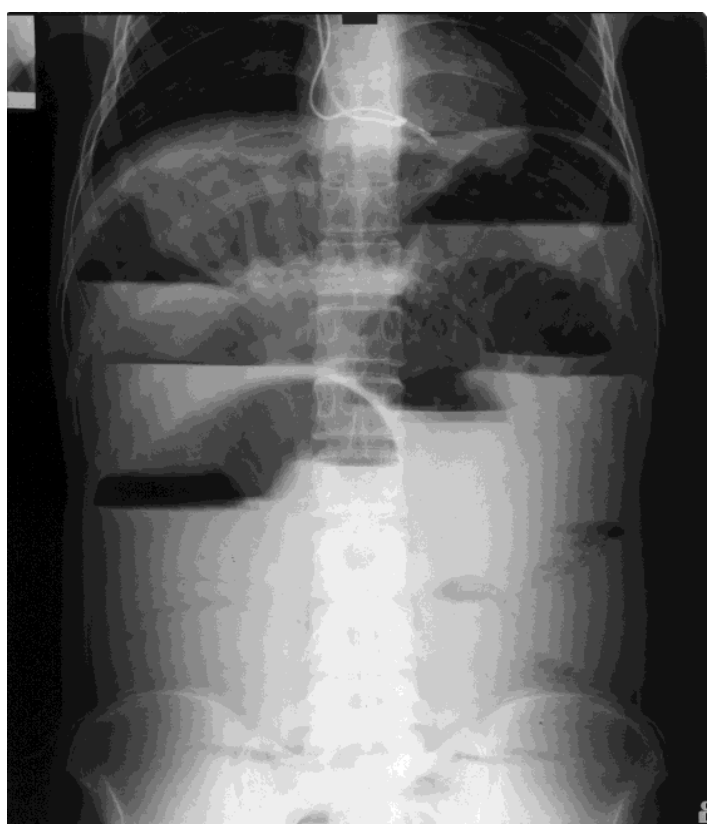

Figure 2. Case 2; depiction of pacemaker shadow and air-fluid levels in standing plain abdominal X-ray.

Small bowel passage radiography demonstrated totally dilated small intestinal segments with edematous walls and the contrast agent given through oral route was observed to pass into the colon at the 24th hour following ingestion. Both colonoscopic and gastroscopic evaluations were normal; duodenal biopsy was unremarkable. No clear reason for a true mechanical lumen-narrowing in the gastrointestinal system could be found out. Motility study revealed a hypomotile esophagus, a gastric emptying time of solids in the upper normal range, a prominently decreased gastric emptying time of fluid foods and a markedly prolonged colonic transit time.

The patient's laboratory data were as follows: hemoglobin $10.4 \mathrm{~g} / \mathrm{dL}$, blood D3 vitamin $13.5 \mathrm{ng} / \mathrm{mL}$ (10-40), parathormon $105 \mathrm{pg} / \mathrm{mL}$ (10-65), albumin $50 \mathrm{~g} / \mathrm{L}$ (35-54), calcium $6.7 \mathrm{mg} / \mathrm{dL}$ (8.4-10.6) and ionized calcium $3.9 \mathrm{mg} / \mathrm{dL}$ (4.2-5.2). Thyroid function tests were detected to be within normal range. As the patient was diagnosed as pseudoobstruction in the small bowel and a resultant hypocalcemia, she was consequently started on a diet providing calcium supplementation, which eventuated in progressive elevation of calcium level to normal value and disappearance of Trousseau sign. The patient was then discharged from the hospital, along with dietary recommendations and prescriptions including prokinetic agent(metoclopramid) and oral calcium+vitamin D preparations.

\section{Discussion}

Chronic intestinal pseudo-obstruction is a rare disorder with inexplicit etiology which is characterized by symptomatic episodes resembling those of a mechanical obstruction in the absence of any organic, systemic or metabolic disease state likely to incur a true mechanical bowel obstruction [4]. It can involve any part of the gastrointestinal system and is classified into either primary or secondary forms. The primary, or congenital, form is more prevalent in children, whereas the secondary, or acquired, form is more prevalent in adults [5-7]. Gastrointestinal system, smooth muscle, nervous system and endocrine system impairments, metabolic and autoimmune disorders, and infectious states (CMV, EBV, etc.) are among the secondary causes [1, 7]. The disorder is termed as chronic idiopathic intestinal pseudo-obstruction (CIIP), should it not be attributed to any genetic or secondary cause [4].

The smooth muscles of the gastrointestinal system are governed by both intrinsic and extrinsic nervous systems. In case the nervous systems are blocked, the intestinal smooth muscle cells are able to be activated spontaneously by a mechanism mediated by the 
interstitial Cajal cells, also known as the intestinal pacemakers. Any injury (through autoimmunity) to these cells would translate into development of chronic intestinal pseudo-obstruction [8].

The clinical findings show variations depending on the area involved [6]. Esophageal involvement is characterized by a prominent dysphagia and gastroesophageal reflux; gastric involvement is characterized by gastroparesis, early satiety, postprandial bloating, nausea, vomiting and abdominal pain; involvement of the small bowel is characterized by nausea, vomiting, abdominal distension, pain and alterations in the intestinal movements, hence bacterial overgrowth and eventual diarrhea; colonic involvement is characterized by constipation $[1,9]$.

Abdominal pain and contractions in the hand were coming into prominence, along with evident abdominal distension in both of our cases. Dilated intestinal segments and contrast passage into the colon at the 24th hour of ingestion indicated small intestinal involvement. Ruling out a true mechanical obstruction has the topmost priority in the diagnosis of chronic intestinal pseudo-obstruction. Imaging methods implemented in either case detected no reason for a mechanical obstruction. Standing plain abdominal Xray depicted air-fluid levels; however, standing plain abdominal X-rays do not prove that much useful in the diagnosis of CIPO and generally demonstrate air-fluid levels and dilations in the intestinal loops [4].

True diagnosis of CIPO is established through a full-thickness biopsy. Moreover, the biopsy specimens should be obtained both from dilated and non-dilated segments via either laparotomy or laparoscopy, and be treated with Smith silver stain so as to reveal myenteric plexus anomalies [10]. A full-thickness biopsy is not necessarily requisite because of the facts that it may incur adhesions and that histological diagnosis does not change the treatment. Should CIIP be evident both clinically and radiologically, gastric emptying and intestinal transit times should be measured using isotope methods in order to exhibit the motility disorder [9]. The laboratory findings in CIPO reflect varying degrees of malabsorption and malnutrition [11]. Malabsorption and malnutrition were evident in our cases both clinically and through laboratory findings. Both of our cases suffered from growth retardation, low body mass index, vitamin D and calcium deficiencies, hence osteoporosis and manifested symptoms of tetany.

A curative treatment for chronic intestinal pseudo-obstruction has still yet to be found. The chief aim of the current treatment is to maintain the fluid and electrolyte balances, as well as to ameliorate the manifest intestinal symptoms [1]. Dietary arrangement is of crucial importance in cases with chronic intestinal pseudo-obstruction, which practically constitutes the basis of the treatment. Foods low in fat and lactose, but rich in polypeptides and fluid content should be preferred. The daily food intake is recommended to be divided into 6 to 8 meals, each meal comprising a maximum of 200-300 kcal. [12]. Flatulence foods should be avoided; moreover, liquid foods should be preferred over solid ones. Liquid foods should be given for a short period of time during symptomatic periods. Any vitamin and mineral deficiency should be corrected through supplementation [1]. Prokinetic agents can be utilized in the pharmacological treatment, yet metoclopramide and domperidone prove ineffective in the treatment. Although Cisapride was demonstrated in clinical studies to confer symptomatic improvement in patients with intact migratory motor complex, it was retired from the market on account of its proarryhtmic effect [13]. Erythromycin has a limited use and its effect is likely to last for a few weeks. However, tachyphlaxis may develop over time. Inhibiting intestinal motility and release of enteric peptides, Octreotide promotes the phase III migratory motor complex activity during fasting. It was found to be effective in the treatment of bacterial overgrowth developing secondary to scleroderma, and has recently been used, along with erythromycin, to benefit from its effect of reducing gastric motility [14].

Surgical treatment comprises only resection or by-pass of damaged small intestinal or 
colonic segments in severely symptomatic cases. But, a precise localization of the diseased segment prior to operation is mandatory. The treatment also encompasses pacemaker applications and small bowel transplantation [15]. Pacemaker can be implanted on the stomach, whereas small intestine is not conducive for this method [6]. Upon failure of all other treatment modalities, detection of hepatic and intestinal failure and in the absence any serious underlying disease, small bowel transplantation may stand for another treatment option. Studies conducted to date reported the 3-year survival rate to be $50-65 \%[16,17]$.

In conclusion, chronic intestinal pseudo-obstruction is a disease state which is likely to be subjected to a challenging and delayed diagnosis. Early and accurate diagnosis would both obviate unnecessary surgeries and take symptoms under control through simple dietary recommendations and nutritional supplementations, thus precluding weight loss and development of malnutrition, and improving the quality of life of patients.

\section{References}

1. Verne GN, Sninsky CA. Chronic intestinal pseudo-obstruction. Dig Dis Sci 1995; 13: $163-81$.

2. Dudley HA, Sinclair IS, McLaren IF, McNair TJ, Newsam JE. Intestinal pseudoobstruction. J R Coll Surg Edinb 1958; 3: 206-17.

3. Maldonado JE, Gregg JA, Green PA, Brown AL Jr. Chronic idiopathic intestinal pseudo-obstruction. Am J Med 1970; 49: 203-12.

4. De Giorgio R, Cogliandro RF, Barbara G, Corinaldesi R, Stanghellini V. Chronic intestinal pseudo-obstruction: Clinical features, diagnosis, and therapy. Gastroenterol Clin North Am 2011; 40: 787-807.

5. Stanghellini V, Cogliandro RF, De Giorgio R, Barbara G, Morselli-Labate AM, Cogliandro L, Corinaldesi R. Natural history of chronic idiopthic intestinal pseudoobstruction in adults: A single center study. Clin Gastroenterol Hepatol 2005; 3: 449-58.

6. Smith DS, Williams CS, Ferris CD. Diagnosis and treatment of chronic gastroparesis and chronic intestinal pseudo-obstruction. Gastroenterol Clin N Am 2003; 32: 619-58.

7. De Giorgio R, Ricciardiello L, Camillari M, Naponelli V, Selgrad M, Piazzi G, Felicani C, Serra M, Fronzoni L, Antonucci A, Cogliandro RF, Barbara G, Corinaldesi R, Tonini M, Knowles CH, Stanghellini V. Chronic intestinal pseudo-obstruction related to viral infections. Transplant Proc 2010; 42: 9-14.

8. Ward SM, Morris G, Reese L, Wang XY, Sanders KM. Interstitial cells of Cajal mediate enteric inhibitory neurotransmission in the lower esophageal and pyloric sphincters. Gastroenterology 1998; 115: 314-29.

9. Lennon VA, Sas DF, Busk MF, Scheithauer B, Malagelada JR, Camilleri M, Miller LJ. Enteric neuronal autoantibodies in pseudo-obstruction with small-cell lung carcinoma. Gastroenterology 1991; 100: 137-42.

10. Di Lorenzo C. Pseudo-obstruction: Current approaches. Gastroenterology 1999; 116: 980-7.

11. Schuffler MD, Rohrmann CA, Chaffee RG, Brand DL, Delaney JH, Young JH. Chronic intestinal pseudo-obstruction: A report of 27 cases and review of the literature. Medicine (Baltimore) 1981; 60: 173-96.

12. Scolapio JS, Ukleja A, Bouras EP, Romano M. Nutritional management of chronic intestinal pseudo-obstruction. J Clin Gastroenterol 1999; 28: 306-12.

13. Camilleri M, Balm RK, Zinsmeister AR. Symptomatic improvement with oneyear cisapride treatment in neuropathic chronic intestinal dysmotility. Aliment Pharmacol Ther 1996; 10: 403-9.

14. Soudah HC, Hasler WL, Owyang C. Effect of ocreotide on intestinal motility and bacterial overgrowth in scleroderma. N Eng J Med 1991; 325: 1461-7. 
15. Murr MM, Sarr MG, Camillari M. The surgeon's role in the treatment of chronic intestinal pseudoobstruction. Am J Gastroenterol 1995; 90: 2147-51.

16. Grant D. Current results of intestinal transplantation: The International Intestinal Transplant Registry. Lancet 1999; 347: 1802.

17. Lapointe R. Chronic idiopathic intestinal pseudo-obstruction treated by near total small bowel resection: A 20-year experience. J Gastrointest Surg 2010; 14: 193742. 